\title{
Eosinophil MBP Extract Modulates Oncogene Expression in Prostate Tumor Cells: A Preliminary Study with Monolayer Cultures
}

\author{
Christine A. Clarke1,2, Michael A. Smith1,2,3, Ibrahim Laniyan1,2, Theresa R. Vaughn2, \\ Debra Parish-Gause ${ }^{2}$, William Green4, Paulette M. Furbert-Harris 1,2,5* \\ ${ }^{1}$ Department of Microbiology, Howard University College of Medicine, Washington DC, USA \\ ${ }^{2}$ Howard University Cancer Center, Howard University College of Medicine, Washington DC, USA \\ ${ }^{3}$ Carolina's Hospital System Marion, Mullins, SC, USA \\ ${ }^{4}$ Department of Pathology, Howard University College of Medicine, Washington DC, USA \\ ${ }^{5}$ National Human Genome Center at Howard University, Howard University College of Medicine, \\ Washington DC, USA \\ Email: pfurbertharris@gmail.com
}

Received 20 February 2015; accepted 26 May 2015; published 29 May 2015

Copyright (C) 2015 by authors and Scientific Research Publishing Inc.

This work is licensed under the Creative Commons Attribution International License (CC BY). http://creativecommons.org/licenses/by/4.0/

(c) (i) Open Access

\section{Abstract}

Prostate cancer is the second leading cause of cancer deaths in the United States and remains a significant health concern for men throughout the world. Despite the discovery of promising immunotherapeutic strategies, curative outcomes remain elusive. We have investigated eosinophils as potential anti-cancer effector cells, and have reported the ability of their toxic granular proteins (MBP, EPO, ECP, EDN) to inhibit prostate tumor cell growth in vitro. This study investigates the effect of eosinophil MBP extract on the expression of oncogenes p53, bcl-xl, bax, and c-myc, which modulate tumor growth, proliferation, and apoptosis. Briefly, granular proteins were differentially extracted from GRC.014.22 and GRC.014.24, eosinophilic cell lines established in our laboratory from a patient with moderate asthma. Protein extracts were fractionated on Sephadex G-50 columns, and prostate tumor cell lines DU-145, LNCaP, PC-3, and HPC8L (established in our laboratory from a tumor resected from an African American patient) were treated with MBP extracts from the pooled third peaks. Colony formation and monolayer cell growth inhibition assays were used to evaluate the protein's growth inhibitory activity against prostate tumor cells; and gene expression analyses, to determine $\mathrm{p53}$, bcl-xl, bax, and c-myc oncogene expression. We show that the granular proteins were potent in their action on HPC8L, inhibiting colony formation in a dose-dependent manner. Treated prostate tumor cell lines trended toward apoptosis-induction, as evident in bcl-xl/bax ratios $<1$, increased p53 expression, and up or downregulation of c-myc. These preliminary results demonstrate the growth inhibitory potential of eosinophil granular

${ }^{*}$ Corresponding author.

How to cite this paper: Clarke, C.A., Smith, M.A., Laniyan, I., Vaughn, T.R., Parish-Gause, D., Green, W. and Furbert-Harris, P.M. (2015) Eosinophil MBP Extract Modulates Oncogene Expression in Prostate Tumor Cells: A Preliminary Study with Monolayer Cultures. Journal of Cancer Therapy, 6, 482-492. http://dx.doi.org/10.4236/jct.2015.66052 
proteins and strongly support the hypothesis that eosinophils modulate the expression of oncogenes associated with prostate tumor proliferation and apoptosis. More importantly, this study offers insights into possible applications of eosinophilic mediators in oncogenic-targeted prostate cancer treatment strategies and demonstrates the potential therapeutic implications of enhancing eosinophilic activity in prostate cancer.

\section{Keywords}

\section{Eosinophils, Major Basic Protein (MBP), Prostate Cancer, HPC8L, Oncogenes}

\section{Introduction}

Prostate cancer is a major public health problem worldwide [1], with estimates of 29,000 deaths per year in the United States [2], and rising incidence and death rates in India, China, and South America [3]. Despite modest improvements in overall survival with outpatient delivered dendritic cell-based immunotherapy [2], there remains very few treatment options for the advanced stage disease. The unrelenting growth of hormone refractory, chemoresistant, and/or radioresistant advanced stage and metastatic prostate cancer is a tremendous challenge for both research investigators and clinicians. There are increasing attempts at the development of more effective therapeutic strategies [4] [5]; however, many, if not all, are associated with side effects resulting in long-term complications, which adversely affect quality of life [5] [6]. The failures of most immunotherapeutic approaches in the past have been due to: a) lack of prostate tumor specific antigens which resulted in high levels of nonspecific immunity; and b) weakly immunogenic tumor specific antigens which elicited less than adequate immune responses [7]. Only moderate success has been achieved with the use of cytokines: high-dose IL-2, IFN- $\alpha$ and IFN- $\gamma$ showed minimal activity against advanced prostate cancer, and objective PSA responses were accomplished only in a small percentage of patients subjected to systemic infusions of GM-CSF as monotherapy [8]. Studies have also shown that, regardless of disease state, the loading of autologous and allogeneic antigens by dendritic cells (DC) and antigen-presenting cells (APC) have elicited immune responses against prostate cancer-associated antigens; however, the majority of prostate cancer patients, including those with survival benefit and slower disease progression, succumb to the disease [2]. Alternative therapeutic strategies have included anti-prostate cancer DNA vaccines [9] [10]; however, these vaccines have been unable to elicit strong clinical immune responses [2]. Recently, promising approaches to prostate cancer therapy have pioneered the use of monoclonal IgGs and chimeric antigen receptor-modified $\mathrm{T}$ cells to target prostate lineage-unique protein (PLUP) antigens, prostate stemcell antigen (PSCA) and prostate cancer-specific membrane antigen (PSMA) [11]. Vigorous studies on anti-androgens are also underway and have been shown to improve metastatic prostate cancer survival, as well as enhance infiltrates of prostate cancer immune effector-cells [12].

The eosinophil has emerged as a potent multi-functional, anti-cancer immune effector cell, with immunoregulatory, cytostatic and cytotoxic capabilities. Eosinophil infiltration has been detected in pathological preparations of tumor tissues of various tumor types [13]-[15]; and, its crystalloids, at prostate tissue sites [16]. Moreover, improved prognosis has been associated with tumor-associated tissue eosinophilia (TATE) or eosinophil degranulation in many solid tumors-including prostate cancer [17]. In the tumor microenvironment, eosinophil degranulation and the resultant antitumor cytotoxic responses are suggested by the observation of cationic granular proteins, major basic protein (MBP), eosinophil cationic protein (ECP), eosinophil derived-neurotoxin (EDN), and eosinophil peroxidase (EPO) [17]. These proteins mediate their toxic effects on tumor cells via destruction and dysfunction of surrounding cells [18]. Despite investigations into the eosinophil's anti-tumor mechanisms, its effect on genes associated with tumor growth, proliferation, and apoptosis has not been well-defined. In the present preliminary study, we examine the effect of eosinophil granular protein, MBP, on the expression of oncogenes p53, bcl-xl, bax, and c-myc in prostate tumor cell lines. These genes are over expressed in prostate cancer and help to induce and maintain continued proliferation, potentiation to metastasis, and resistance to all forms of radiotherapy. Over expression of p53, EGFR, and her2/neu was demonstrated in metastatic hormone-refractory prostate cancer and were suggested as more suitable for therapeutic strategies [19]. Concato et al. and their retrospective immunohistochemical analyses of 1313 patient samples revealed increased presence 
of bcl-2 and p53 and found these expressions to be associated with an increased long-term risk for death from prostate cancer [20]. Clinical studies by Scherr et al. evaluating the expression of p53 and bcl-2 relative to treatment outcomes suggested that bcl-2 and p53 presence in pretreatment specimens might predict response to radiotherapy; and Pollack et al. concluded that abnormal expression of bcl-2 and bax were associated with resistance to radiotherapy [21] [22]. Bcl-2 confers a survival advantage to cells with its anti-apoptotic properties; its over expression underlies the aggressive behavior of prostate cancer cells, and it has been shown to induce resistance in vivo to androgen depletion therapy. Bax on the other hand is proapoptotic and reduced or no expression would complement bcl-2 overexpression and lead to resistance [23]-[26]. C-Myc is an early response gene that plays a critical role in cell cycle progression from G1 to S [27] [28]. It is also active in G2/M transition and is thus important in the complete regulation of the cell cycle [29]. The deregulation of c-myc in human cancers is well documented, and this gene is known to be amplified in some prostate cancers, including the hormone refractory type [30]-[32].

Given the eosinophil's anti-cancer properties and the emergence of oncogenes or molecular markers of cell cycle growth and apoptosis as more suitable prognosticators and targets for prostate cancer treatment strategies, we have elected to isolate eosinophil MBP extract from immortalized eosinophil cell cultures in order to study the granular protein's effect on the expression of pro-apoptotic genes p53 and bax, anti-apoptotic gene bcl-xl, and cell proliferation index c-myc in monolayer cultures of DU-145, LNCaP, PC-3, and the newly established HPC8L human prostate tumor cell line.

\section{Materials and Methods}

\subsection{Cell Lines}

\subsubsection{Eosinophilic Cell Lines}

The eosinophilic cell lines, GRC.014.22 and GRC.014.24, were established in our laboratory and their isolation previously described [33]. Briefly, peripheral blood leukocytes from an eosinophilic asthmatic individual were fractionated on a metrizamide density gradient, and hypo-dense $\left(\mathrm{M}_{22}\right)$ and normo-dense $\left(\mathrm{M}_{24}\right)$ eosinophilic fractions transformed with Epstein-Barr virus.

\subsubsection{Prostate Tumor Cell Lines}

Prostate tumor cell lines PC-3, DU-145, and LNCaP were purchased from American Type Culture Collection (ATCC), Manassas, VA. The HPC8L prostate tumor cell line was established in our laboratory from tissue specimens of an excised tumor resected from an African American patient, and was partially characterized using prostate cancer cell markers, the motility marker vimentin, and cytokeratins, to determine the cellular nature of the cell line.

\subsection{Isolation of Eosinophil MBP Extract}

Eosinophil granules were isolated from eosinophilic cell lines GRC.014.22 and GRC.014.24 using a modified procedure of Durack et al. and Slifman et al. [34] [35]. Briefly, eosinophilic cells were washed with $0.34 \mathrm{M}$ sucrose then lysed in sucrose-heparinated solution (0.34 M sucrose solution with 250 units/ml heparin). After removal of cellular debris by centrifugation at $1000-1500 \mathrm{~g}$, granules were pelleted at 20,000 - 25,000 $\mathrm{g}$ for 20 minutes, then washed with ice cold PBS. Granular pellets were pooled and granular proteins isolated by repeat dissolution in $0.01 \mathrm{~N} \mathrm{HCL}$, collecting and storing 21 individual fractions. Extracts were concentrated using amicon $^{\mathrm{R}}$ filtration, fractionated on a $1.2 \times 47 \mathrm{~cm}$ Sephadex G-50 column, and quantified using BioRad Experion Protein Quantitation Kit ${ }^{\mathrm{R}}$ (BioRad, CA). Fractions from the third peaks (shown by Ohnuki et al. to contain the 14 kDa Major Basic Protein [36]) were pooled, stabilized by reduction and alkylation of sulfhydryl groups, and resolved by SDS-PAGE using Ready Gel precast gels (BioRad), 15\% Tris-HCL.

\subsection{Prostate Tumor Growth Inhibition by Eosinophil MBP Extract}

\subsubsection{Colony Formation Inhibition Assay}

HPC8L tumor cells were seeded in 6-well tissue culture plates (100 cells/well) and incubated overnight at $37^{\circ} \mathrm{C}$, $5 \% \mathrm{CO}_{2}$ and $95 \%$ air humidified conditions. On day 2, the cells were treated with eosinophil MBP extract at varying concentrations $(1000-25,000 \mathrm{ng} / \mathrm{ml})$. The plates were then incubated for 10 days. At the end of the incu- 
bation period, the media were removed, the wells washed with PBS, the colonies stained with hematoxylin and eosin (H \& E), and then counted manually. Percent inhibition of colony formation was calculated using the following equation.

$$
\% \text { Inhibiton of colony formation }=\left[\frac{\text { Average no. of colonies }(\text { control })-\text { Average no. of colonies }(\text { test }) \times 100}{\text { Average no. of colonies }(\text { control })}\right]
$$

\subsubsection{Monolayer Growth Assay}

HPC8L, PC-3, DU-145 and LNCaP tumor cells were seeded into 6-well culture plates at $3 \times 10^{5}$ cells/well. The plates were incubated for $24 \mathrm{hrs}$ at $37^{\circ} \mathrm{C}$ in an atmosphere of $5 \% \mathrm{CO}_{2}$ and $95 \%$ air. The media were removed at the end of the incubation. Subconfluent cultures were treated with single doses of eosinophil MBP extract (1000 $\mathrm{ng} / \mathrm{ml}$ ) for 24 - $72 \mathrm{hrs}$ (the time at which control wells [media alone] became confluent). The cells were subsequently harvested, RNA extracted, and probed for p53, bcl-xl, bax and c-myc oncogene expression using RT-PCR.

\subsection{Gene Expression Analysis in Extract-Treated Prostate Tumor Cultures}

Total RNA was extracted from treated monolayer culture, purified using a Purescript ${ }^{\mathrm{R}}$ RNA Purification Kit (Gentra Systems, Minneapolis, MN), and relative gene expression of p53, bcl-xl, bax, and c-myc determined using the iQ5 Real-Time PCR Systems (BioRad, Hercules, CA). Briefly, $1 \mu \mathrm{g}$ total RNA was reverse transcribed into cDNA using iScript cDNA Synthesis Kit ${ }^{R}$ (BioRad, Hercules, CA.) in a total volume of $20 \mu l$. TaqMan Gene Expression RT-PCR $\mathrm{kit}^{\mathrm{R}}$ was used to analyze oncogene expression (GAPDH was used as the control gene). A 25 $\mu 1$ reaction mix [2× TaqMan universal PCR master mix $(12.5 \mu \mathrm{l}), 20 \times$ target primer/probes $(1.25 \mu \mathrm{l})$, and RNAse free water $(10.25 \mu \mathrm{l})]$ was kept for $2 \mathrm{~min}$ at $50^{\circ} \mathrm{C}, 10 \mathrm{~min}$ at $95^{\circ} \mathrm{C}$, and then subjected to 40 cycles $\left(15 \mathrm{~min}\right.$ at $95^{\circ} \mathrm{C}$ for melting step and $1 \mathrm{~min}$ at $60^{\circ} \mathrm{C}$ for annealing step). The assay was performed using the BioRad IQ5 Multicolor Real-Time PCR Detection System and the data analyzed using the IQ5 Optical System Software.

\subsection{Statistical Analysis}

All assays listed above in this study were run in duplicates in at least two separate independent sets of experiments performed during the course of the study. Data were presented as mean \pm standard error. The differences among different groups of treatments were analyzed using one-way analysis of variance (ANOVA), with statistical significance measured by Student's t-test.

\section{Results}

\subsection{Characterization of HPC8L Cell Line}

HPC8L prostate tumor cell line was studied by means of anchorage-independent growth in soft agar and positive staining for several prostate markers. The cells are positive for androgen receptor, prostate specific antigen, epithelial membrane antigen, and keratin 8, as shown in photomicrographs of Figure 1. These cells also stained positive for vimentin, similar to DU-145, as depicted in Figure 1(D) and Figure 1(I). We further characterized this cell line by injecting $1 \times 10^{7}$ cells into flanks of male nude mice. The tumors grew slowly in the nude mice. It took approximately 8 months to grow $1 \mathrm{~cm}^{3}$ tumors with this number of tumor cells injected into the flanks of male nude mice. Contrary to its slow growth in vivo, this cell line and its primary grew prolifically in tissue culture. A representative photomicrograph is shown in Figure 2. The histopathologic findings show round to polygonal cells with moderately abundant cytoplasm and nuclei with prominent nucleoli. The tumor cells had extensively infiltrated the mouse soft tissue.

\subsection{Electrophoretic Analysis of Granular Protein Extracts}

SDS-PAGE analysis of $21 \mathrm{HCl}$ extractions from eosinophil granules revealed molecular weight bands for MBP, EPO, ECP, EDN, and granzyme B. Figure 3 shows the detection of Major Basic Protein (14 kDa); Granzyme B (25 kDa); Eosinophil Cationic Protein (18 - $22 \mathrm{kDa})$; Eosinophil Derived Neurotoxin (18.4 kDa); and Eosinophil Peroxidase $(7.7 \mathrm{kDa})$. All detected proteins have been implicated in the eosinophil's anti-tumor mechanism. Fractions from pooled third peaks corresponded to a $14 \mathrm{kDa}$ eosinophil protein referred to as MBP. 


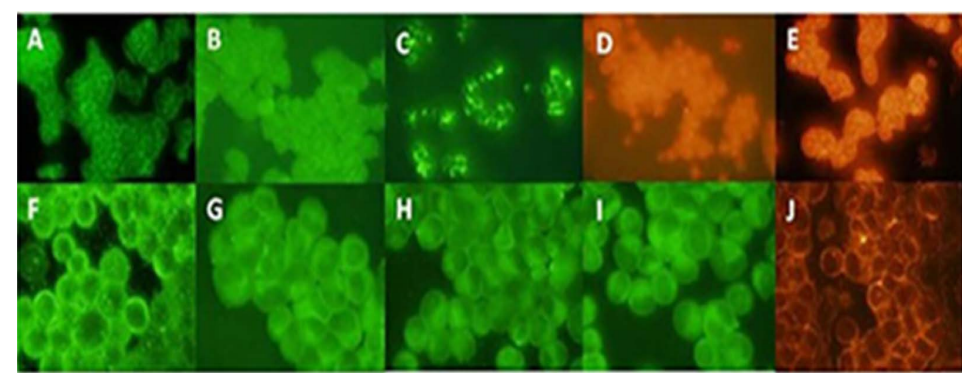

Figure 1. Immunohistochemical Staining of HPC8L for Prostate Specific Markers. Cytospin slices of HPC8L tumor cells at $2 \times 10^{5} / \mathrm{ml}(200 \mu \mathrm{l})$ were prepared and fixed with methanol. Cytospin slides of DU-145 prostate tumor cells were similarly prepared and used as positive controls. The slides were then stained for various prostate markers (AR, PSA, EMA, Vimentin and Cytokeratin 8), using the following primary antibodies: mouse anti-human androgen receptor Ab-1 (Neomarkers, Fremont, CA); rabbit anti-human prostate specific antigen; mouse anti-human epithelial antigen; mouse anti-vimentin, V9; and mouse anti-human cytokeratin 8 (Dako Corporation, Carpinteria, CA). HPC8L vimentin and cytokeratin 8, and DU-145 cytokeratin 8 were stained with texas red-conjugated goat anti-mouse antibody (Abcam, Cambridge, MA). PSA was stained using fluorescein-conjugated goat anti-rabbit antibody; and HPC8L markers AR, EMA, and DU-145 AR, EMA and vimentin stained using fluorescein-conjugated rat anti-mouse secondary antibody (BD Pharmingen, San Diego, CA). Photomicrographs were captured at 20× magnification using an Olympus $1 \times 71$ fluorescent microscope with DP70 camera system.

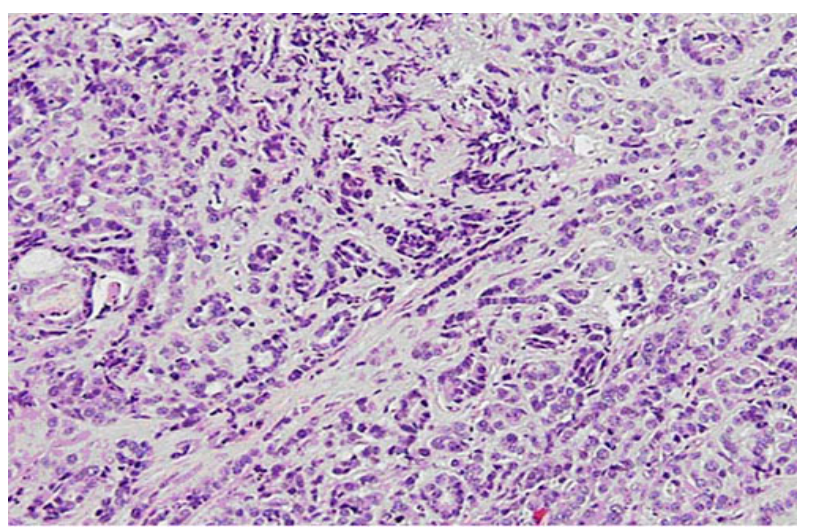

Figure 2. The tumor cells form small acini and cords which infiltrate the mouse soft tissue.

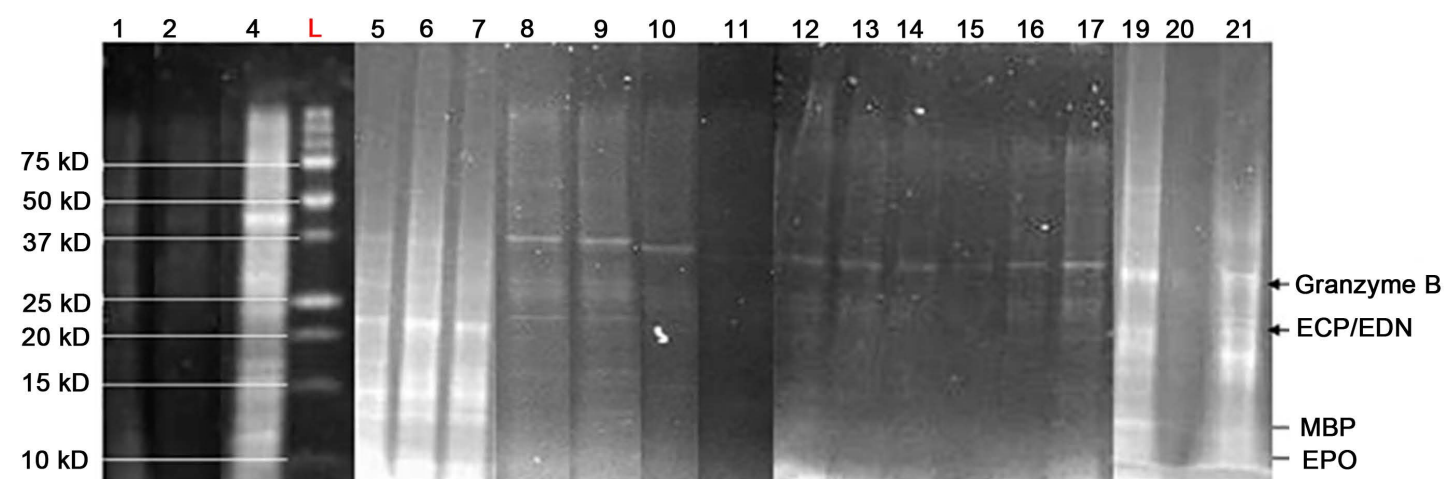

Figure 3. Composite SDS-PAGE Profile of Eosinophil Granular Proteins Isolated from Cultured Eosinophil Cell Lines, GRC.014.22 and GRC.014.24. Twenty one HCL-extracted fractions were collected from eosinophil cellular granules. Based on molecular weight, granular proteins MBP (13.8 - 14 kDa), EPO (7.7 kDa), EDN (18.4 $\mathrm{kDa})$, ECP (18 - $22 \mathrm{kDa})$ and Granzyme B (25 kDa) can be detected. Granzyme B was detected in fractions 1 - 17; EDN/ECP in fractions 5 - 10, 17, 19 and 21; MBP in fractions $4-7,19$ and 21. 


\subsection{Effect of MBP Extract on HPC8L Prostate Tumor Colony Formation}

As shown in Figures 4(A) and Figures 4(B), MBP granular extract was effective in inhibiting HPC8L tumor cell colony formation. The granular extract at a concentration of $25,000 \mathrm{ng} / \mathrm{ml}$ produced $24 \%$ colony growth inhibition. The extract significantly inhibited HPC8L colony formation in a dose-dependent manner.

\subsection{Effect of MBP Extract on p53, bcl-xl, bax, and c-myc Expression in DU145, LNCaP, PC-3 and HPC8L Prostate Tumor Cell Lines}

When monolayer cultures of prostate cells were examined for onogene expression, MBP extract upregulated the expression of p53 at 48 hrs in LNCaP (Figure 5(A)); bcl-xl at 24 hrs in HPC8L (Figure 5(B)); bax at 24 hrs in HPC8L, and at 24 and 48 hrs in LNCaP (Figure 5(C)). C-myc was minimally affected by treatment, except at $48 \mathrm{hrs}$ when it was significantly upregulated in LNCaP and significantly downregulated in HPC8L (Figure 5(D)). At early treatment time points, MBP treatment resulted in bcl-xl/bax ratios $<1$ in LNCaP, and at 24 and 48 hrs for DU-145 and HPC8L, respectively. P53 expression was upregulated in DU-145, LNCaP, and HPC8L, and at 72 hrs, c-myc was significantly reduced in HPC8L. This data strongly suggest apoptosis-like induction. Fold changes greater than or equal to two were considered significant.

\section{Discussion}

Prostate cancer remains one of the most commonly diagnosed malignancies and a continuous health concern globally. Current therapies offer limited efficacy to patients, particularly in advanced disease, which if unchecked, eventually becomes metastatic and incurable [4] [5]. The development of prostate cancer involves complex me-

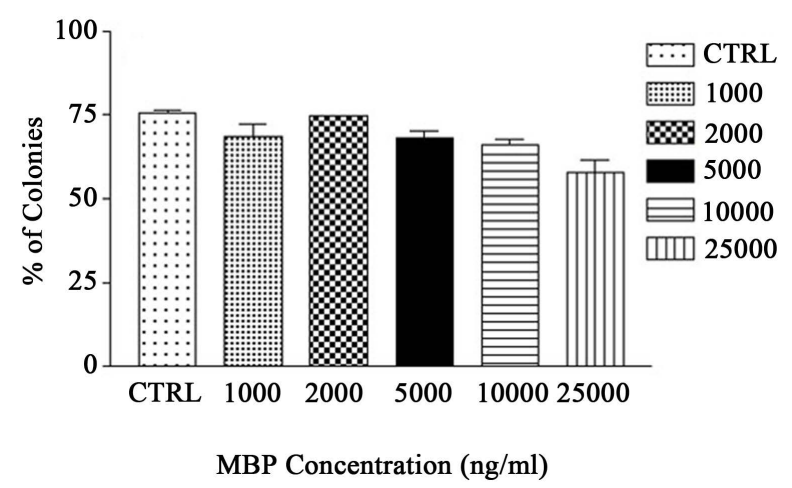

(A)

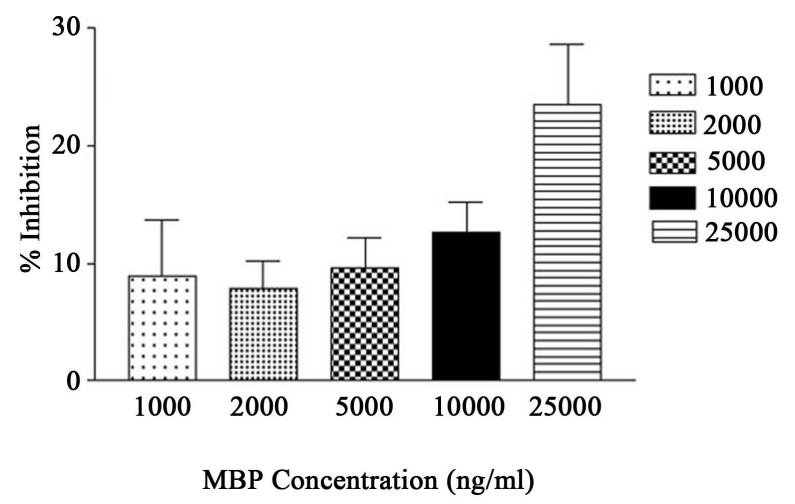

(B)

Figure 4. (A) and (B) Effect of Eosinophil Granular Protein Extract on HPC8L Colony Formation. HPC8L cells were seeded into 6-well culture plates at 100 cells/well and incubated overnight at 37C, 5\% $\mathrm{CO}_{2}, 95 \%$ air, humidified conditions. At 24 hrs, the cells were treated with protein extract $(1000-25,000$ $\mathrm{ng} / \mathrm{ml})$. The plates were further incubated for 10 days, harvested, fixed and stained with hematoxalin and eosin, then counted manually. 


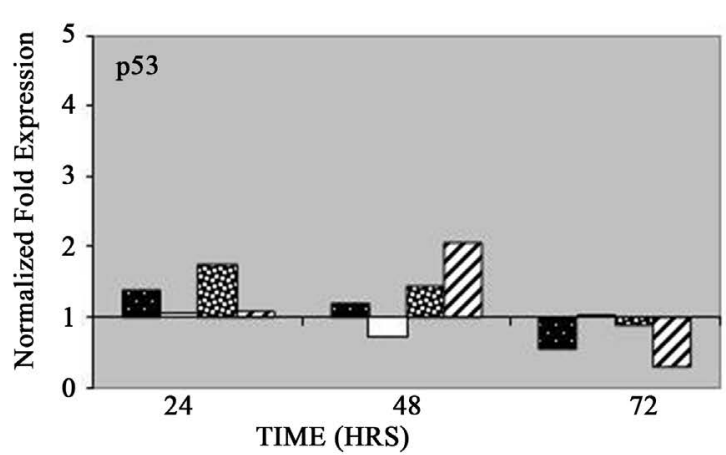

(A)

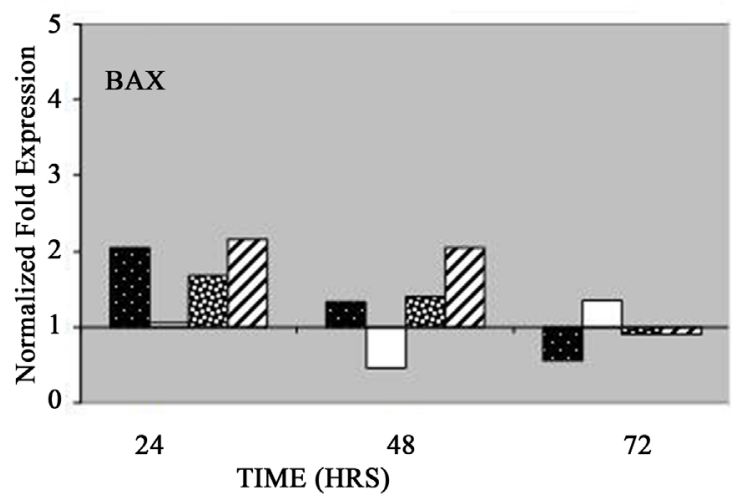

(C)

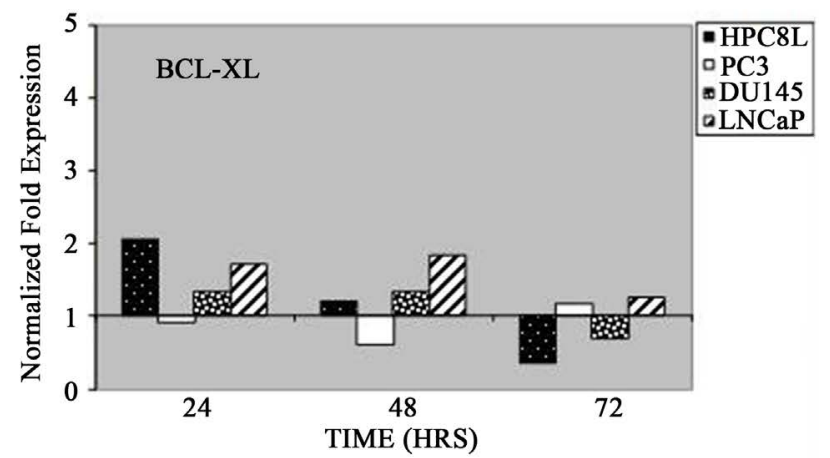

(B)

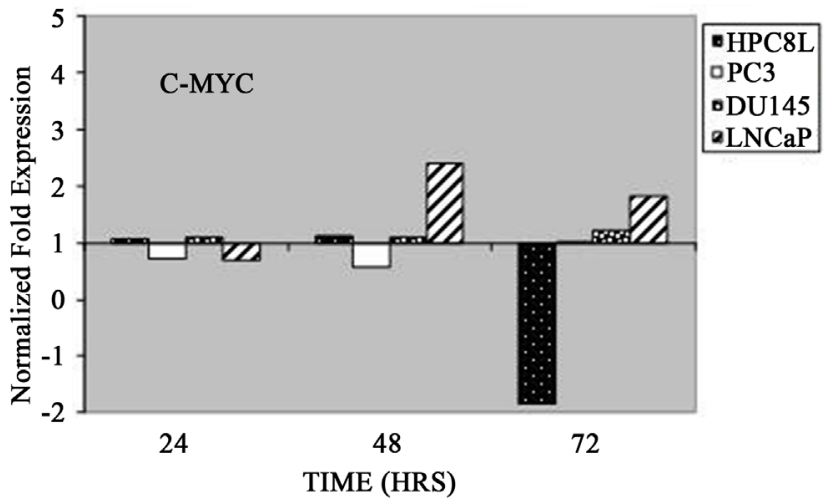

(D)

Figure 5. Effect of Eosinophil Granular Protein Extract on Oncogene Expression in Prostate Cancer Cell Lines. Six-well sub-confluent cultures of HPC8L, PC-3, DU-145 and LNCaP prostate tumor cells $\left(3 \times 10^{5}\right.$ cells/ml) were treated with the protein extract $(1000 \mathrm{ng} / \mathrm{ml})$ for $24 \mathrm{hrs}, 48 \mathrm{hrs}$ and $72 \mathrm{hrs}$. The cells were harvested, RNA extracted and probed for p53, bcl-xl, bax and c-myc oncogene expression using RT-PCR method. The data were normalized to the control GAPDH expression.

chanisms, and molecular studies examining mechanisms of prostate tumor growth, proliferation, and apoptosis are important for the identification of new therapeutic strategies.

In this study, we described for the first time a new prostate tumor cell line, HPC8L. This cell line consisted of poorly differentiated prostate carcinoma cells that stained positive for androgen receptor, prostate specific antigen, epithelial membrane antigen, and vimentin. The cell line was established from an excised fresh tumor resected from an African American patient and the use of this specimen was approved by the Howard University Institutional Review Board. This cell line grew prolifically in cell culture, but slowly in flanks of nude mice. The slow growth in nude mice suggested that its in vivo growth might require supplementation with testosterone or 5-dihydrotestosterone injection, just as the human breast cancer cell line, MCF-7, requires $17-\beta$-estradiol implantation to support its growth in flanks of female nude mice. HPC8L, along with androgen-dependent LNCaP, androgen-independent PC-3, and DU-145 prostate tumor cell lines, were used to investigate the effect of eosinophil granular MBP extract on the expression of a panel of oncogenes (p53, bcl-xl, bax and c-myc), which play a significant role in cancer growth and apoptosis. The overexpression of these oncogenes has been shown to induce and maintain proliferation, as well as promote metastasis and resistance to radiotherapy. The tumor suppressor gene, p53, is considered the "guardian of the genome" under normal conditions of cell growth. Under stress conditions of DNA assault by oncogenes, drug-induced and radiation-induced DNA damage p53 expression is upregulated, and functions to either induce cell cycle arrest to allow for DNA repair, or directs the cell to undergo programmed cell death or apoptosis [37]. The bcl-2 family of proteins is also involved in regulating apoptosis. This family of genes comprises a subset that is anti-apoptotic (e.g., bcl-xl) and a set that is proapoptotic (e.g., bax). The ratio of expression of bcl-xl to bax is significant in determining pro- or anti-apoptosis [38] [39]. Bcl-xl/bax ratio $>1$ is predictive of anti-apoptosis and, therefore, cell survival, while ratios $<1$ are predictive of apoptosis and cell death [39] [40]. C-myc is the cell proliferation index that plays a critical role in the progression and regulation of the cell 
cycle [27]-[29].

MBP extract was isolated from eosinophilic cell lines previously established in our laboratory. We have used studies confirming MBP's presence in the third peaks of fractionated eosinophil granular extracts [36] as the basis for speculating that the protein in our pooled third peak fractions is our characteristic protein of interest, MBP. At early treatment times, MBP extract treatment resulted in bcl-xl/bax ratios $<1$ in LNCaP, and DU-145 and HPC8L at 24 and 48 hrs, respectively. P53 expression was upregulated in all prostate tumor lines at early treatment times, while at 72 hrs, c-myc was markedly reduced in HPC8L-all indicative of apoptosis induction. C-myc was over expressed in LNCaP and DU-145. Our results have been affirmed in a number of studies that have shown apoptosis-induction with both increased and decreased c-myc levels [41]-[43]. The over expression of c-myc, particularly in LNCaP and DU 145, and the related overexpression of bax observed in this study, have also been previously reported [44]. These observations beg additional studies to further elucidate the effect of MBP on genes that modulate prostate tumor cell growth.

In addition to modulating oncogene expression, we also examined the growth inhibitory effect of eosinophilic MBP extract on the newly established prostate tumor cell line, HPC8L. MBP extract significantly inhibited HPC8L tumor cell colony formation in a dose-dependent manner-with $24 \%$ colony growth inhibition at 25,000 $\mathrm{ng} / \mathrm{ml}$. Previous reports have also confirmed toxicity of eosinophil granular proteins towards tumor cells [45] [46], as well as the ability of eosinophils to retard tumor cell growth and clonogenic potential in eosinophil: tumor cell monolayer co-culture experiments [7] [47]. In addition, our previous studies have demonstrated significant inhibition of PC-3 and DU-145 tumor cell colony formation upon treatment of monolayer cultures with eosinophil conditioned media (supernatants) [7]. Similar growth inhibitory effects were also evident in monolayer cultures of MCF-7 breast cancer cell line treated with eosinophil supernatants [47]. Thus, the inhibitory effects of eosinophil supernatants are, therefore, not tumor-tissue or cancer cell-line specific. Equally important, are our previous studies indicating the release of MBP - one of the eosinophil's artillery of degranulation products - into culture media, and its putative role inhibiting tumor cell growth [7] [47]. MBP and cytokines, such as tumor necrosis factor alpha (TNF- $\alpha$ ) and interleukin (IL)-2, $-4,-5$ and -6, are found in cell-free supernatants of eosinophil cultures. These proteins are produced and released into the supernatants by secondary granules, which are characteristic of eosinophils. MBP is present in the prominent crystalloid core, along with cytokines IL-2, IL-4, and GM-CSF, while the other secondary granular proteins, ECP, EPO and EDN are found in the matrix, along with TNF- $\alpha$ and IL-6 [48]. To the best of our knowledge, the inhibitory effects of our MBP extract on monolayer cultures of these prostate tumor cell lines are a new observation.

In summary, these preliminary results suggest, for the first time, that eosinophil granular MBP extract modulates oncogene expression and induces apoptosis in prostate tumor cells—as indicated by bcl-xl/bax ratios $<1$, increased p53 expression, and up or downregulation of c-myc. The precise mechanisms underlying our observations are currently unknown, and further studies are necessary to explore the nature of this modulation. Future studies will include western blots and apoptosis-studies to confirm, respectively, the presence of MBP-the specific protein of interest in our study —and apoptotic cell death in MBP-treated prostate tumor cells. Given that the ratios of oncogene expression are predictive of response to cancer therapeutic agents and radiotherapy, and that apoptosis induction is a key indicator of an anti-cancer drug's effectiveness, our preliminary findings beg complimentary studies to further investigate the anti-tumor capabilities of eosinophils and their granular constituents, as well as their potential application in prostate cancer immunotherapy.

\section{Acknowledgements}

This project was supported in part with funds from US Army Medical Research and Material Command DOD DAMD17-98-8485.

\section{References}

[1] Zhang, Z., Li, M., Wang, H., Agrawal, S. and Zhang, R. (2003) Antisense Therapy Targeting MDM2 Oncogene in Prostate Cancer: Effects on Proliferation, Apoptosis, Multiple Gene Expression, and Chemotherapy. Proceedings of the National Academy of Sciences of the United States of America, 100, 11636-11641. http://dx.doi.org/10.1073/pnas.1934692100

[2] Simons, J.W. (2014) Prostate Cancer Immunotherapy: Beyond Immunity to Curability. Cancer Immunology Research, 2, 1034-1043. http://dx.doi.org/10.1158/2326-6066.CIR-14-0174 
[3] Hu, Y., Zhao, Q., Rao, J., Deng, H., Yuan, H. and Xu, B. (2014) Longitudinal Trends in Prostate Cancer Incidence, Mortality, and Survival of Patients from Two Shanghai City Districts: A Retrospective Population-Based Cohort Study, 2000-2009. BMC Public Health, 14, 356. http://dx.doi.org/10.1186/1471-2458-14-356

[4] Gomella, L.G., Johannes, J. and Trabulsi, E.J. (2009) Current Prostate Cancer Treatments: Effect on Quality of Life. Urology, 73, 28-35. http://dx.doi.org/10.1016/j.urology.2009.03.003

[5] Moon, C., Park, J.C., Chae, Y.K., Yun, J.H. and Kim, S. (2008) Current Status of Experimental Therapeutics for Prostate Cancer. Cancer Letters, 266, 116-134. http://dx.doi.org/10.1016/j.canlet.2008.02.065

[6] Schwandt, A. and Garcia, J.A. (2009) Complications of Androgen Deprivation Therapy in Prostate Cancer. Current Opinion in Urology, 19, 322-326. http://dx.doi.org/10.1097/MOU.0b013e32832a082c

[7] Furbert-Harris, P., Parish-Gause, D., Laniyan, I., Hunter, K.A., Okomo-Awich, J., Vaughn, T.R. and Oredipe, O.A. (2003) Inhibition of Prostate Cancer Cell Growth by Activated Eosinophils. Prostate, 57, 165-175. http://dx.doi.org/10.1002/pros.10286

[8] Rini, B.I., Weinberg, V., Bok, R. and Small, E.J. (2003) Prostate-Specific Antigen Kinetics as a Measure of the Biologic Effect of Granulocyte-Macrophage Colony-Stimulating Factor in Patients with Serologic Progression of Prostate Cancer. Journal of Clinical Oncology, 21, 99-105.

[9] Alam, S. and McNeel, D.G. (2010) DNA Vaccines for the Treatment of Prostate Cancer. Expert Review of Vaccines, $\mathbf{9}$, 731-745. http://dx.doi.org/10.1586/erv.10.64

[10] Becker, J.T., Olson, B.M., Johnson, L.E., Davies, J.G., Dunphy, E.J. and McNeel, D.G. (2010) DNA Vaccine Encoding Prostatic Acid Phosphatase (PAP) Elicits Long-Term T-Cell Responses in Patients with Recurrent Prostate Cancer. Journal of Immunotherapy, 33, 639-647. http://dx.doi.org/10.1097/CJI.0b013e3181dda23e

[11] Tagawa, S.T., Beltran, H., Vallabhajosula, S., Goldsmith, S.J., Osborne, J., Matulich, D. and Bander, N.H. (2010) AntiProstate-Specific Membrane Antigen-Based Radioimmunotherapy for Prostate Cancer. Cancer, 116, 1075-1083. http://dx.doi.org/10.1002/cncr.24795

[12] Mercader, M., Bodner, B.K., Moser, M.T., Kwon, P.S., Park, E.S., Manecke, R.G. and Kwon, E.D. (2001) T Cell Infiltration of the Prostate Induced by Androgen Withdrawal in Patients with Prostate Cancer. Proceedings of the National Academy of Sciences of the United States of America, 98, 14565-14570. http://dx.doi.org/10.1073/pnas.251140998

[13] Fernandez-Acenero, M.J., Galindo-Gallego, M., Sanz, J. and Aljama, A. (2000) Prognostic Influence of Tumor-Associated Eosinophilic Infiltrate in Colorectal Carcinoma. Cancer, 88, 1544-1548. http://dx.doi.org/10.1002/(SICI)1097-0142(20000401)88:7<1544::AID-CNCR7>3.0.CO;2-S

[14] Iwasaki, K., Torisu, M. and Fujimura, T. (1986) Malignant Tumor and Eosinophils. I. Prognostic Significance in Gastric Cancer. Cancer, 58, 1321-1327. http://dx.doi.org/10.1002/1097-0142(19860915)58:6<1321::AID-CNCR2820580623>3.0.CO;2-O

[15] Pretlow, T.P., Keith, E.F., Cryar, A.K., Bartolucci, A.A., Pitts, A.M., Pretlow, T.G. and Boohaker, E.A. (1983) Eosinophil Infiltration of Human Colonic Carcinomas as a Prognostic Indicator. Cancer Research, 43, 2997-3000.

[16] Luna-More, S., Florez, P., Ayala, A., Diaz, F. and Santos, A. (1997) Neutral and Acid Mucins and Eosinophil and Argyrophil Crystalloids in Carcinoma and Atypical Adenomatous Hyperplasia of the Prostate. Pathology, Research and Practice, 193, 291-298. http://dx.doi.org/10.1016/S0344-0338(97)80006-4

[17] Davis, B.P. and Rothenberg, M.E. (2014) Eosinophils and Cancer. Cancer Immunology Research, 2, 1-8. http://dx.doi.org/10.1158/2326-6066.CIR-13-0196

[18] Shi, H.Z. (2004) Eosinophils Function as Antigen-Presenting Cells. Journal of Leukocyte Biology, 76, 520-527. http://dx.doi.org/10.1189/jlb.0404228

[19] Zellweger, T., Ninck, C., Bloch, M., Mirlacher, M., Koivisto, P.A., Helin, H.J. and Bubendorf, L. (2005) Expression Patterns of Potential Therapeutic Targets in Prostate Cancer. International Journal of Cancer, 113, 619-628. http://dx.doi.org/10.1002/ijc.20615

[20] Concato, J., Jain, D., Uchio, E., Risch, H., Li, W.W. and Wells, C.K. (2009) Molecular Markers and Death from Prostate Cancer. Annals of Internal Medicine, 150, 595-603. http://dx.doi.org/10.7326/0003-4819-150-9-200905050-00005

[21] Pollack, A., Cowen, D., Troncoso, P., Zagars, G.K., von Eschenbach, A.C., Meistrich, M.L. and McDonnell, T. (2003) Molecular Markers of Outcome after Radiotherapy in Patients with Prostate Carcinoma: Ki-67, Bcl-2, Bax, and Bcl-x. Cancer, 97, 1630-1638. http://dx.doi.org/10.1002/cncr.11230

[22] Scherr, D.S., Vaughan Jr., E.D., Wei, J., Chung, M., Felsen, D., Allbright, R. and Knudsen, B.S. (1999) Bcl-2 and p53 Expression in Clinically Localized Prostate Cancer Predicts Response to External Beam Radiotherapy. Journal of Urology, 162, 12-16. http://dx.doi.org/10.1097/00005392-199907000-00003

[23] An, J., Chervin, A.S., Nie, A., Ducoff, H.S. and Huang, Z. (2007) Overcoming the Radioresistance of Prostate Cancer Cells with a Novel Bcl-2 Inhibitor. Oncogene, 26, 652-661. http://dx.doi.org/10.1038/sj.onc.1209830 
[24] Cao, W., Yacoub, S., Shiverick, K.T., Namiki, K., Sakai, Y., Porvasnik, S. and Rosser, C.J. (2008) Dichloroacetate (DCA) Sensitizes Both Wild-Type and Over Expressing Bcl-2 Prostate Cancer Cells in Vitro to Radiation. The Prostate, 68, 1223-1231. http://dx.doi.org/10.1002/pros.20788

[25] Raffo, A.J., Perlman, H., Chen, M.W., Day, M.L., Streitman, J.S. and Buttyan, R. (1995) Overexpression of Bcl-2 Protects Prostate Cancer Cells from Apoptosis in Vitro and Confers Resistance to Androgen Depletion in Vivo. Cancer Research, 55, 4438-4445.

[26] Khor, L.Y., Moughan, J., Al-Saleem, T., Hammond, E.H., Venkatesan, V., Rosenthal, S.A. and Pollack, A. (2007) Bcl-2 and Bax Expression Predict Prostate Cancer Outcome in Men Treated with Androgen Deprivation and Radiotherapy on Radiation Therapy Oncology Group Protocol 92-02. Clinical Cancer Research, 13, 3585-3590. http://dx.doi.org/10.1158/1078-0432.CCR-06-2972

[27] Heikkila, R., Schwab, G., Wickstrom, E., Loke, S.L., Pluznik, D.H., Watt, R. and Neckers, L.M. (1987) A c-Myc Antisense Oligodeoxynucleotide Inhibits Entry into $S$ Phase but Not Progress from $G_{0}$ to $G_{1}$. Nature, 328, 445-449. http://dx.doi.org/10.1038/328445a0

[28] Obaya, A.J., Mateyak, M.K., and Sedivy, J.M. (1999) Mysterious Liaisons: The Relationship between c-Myc and the Cell Cycle. Oncogene, 18, 2934-2941. http://dx.doi.org/10.1038/sj.onc.1202749

[29] Adachi, S., Obaya, A.J., Han, Z., Ramos-Desimone, N., Wyche, J.H. and Sedivy, J.M. (2001) c-Myc Is Necessary for DNA Damage-Induced Apoptosis in the $\mathrm{G}_{2}$ Phase of the Cell Cycle. Molecular and Cellular Biology, 21, 4929-4937. http://dx.doi.org/10.1128/MCB.21.15.4929-4937.2001

[30] Bernard, D., Pourtier-Manzanedo, A., Gil, J. and Beach, D.H. (2003) Myc Confers Androgen-Independent Prostate Cancer Cell Growth. Journal of Clinical Investigation, 112, 1724-31. http://dx.doi.org/10.1172/JCI200319035

[31] Dang, C.V. (1999) c-Myc Target Genes Involved in Cell Growth, Apoptosis, and Metabolism. Molecular and Cellular Biology, 19, 1-11.

[32] Fleming, W.H., Hamel, A., MacDonald, R., Ramsey, E., Pettigrew, N.M., Johnston, B. and Matusik, R.J. (1986) Expression of the c-Myc Protooncogene in Human Prostatic Carcinoma and Benign Prostatic Hyperplasia. Cancer Research, 46, 1535-1538.

[33] Vadas, M.A., David, J.R., Butterworth, A., Pisani, N.T. and Siongok, T.A. (1979) A New Method for the Purification of Human Eosinophils and Neutrophils, and a Comparison of the Ability of These Cells to Damage Schistosomula of Schistosoma mansoni. Journal of Immunology, 122, 1228-1236.

[34] Durack, D.T., Ackerman, S.J., Loegering, D.A. and Gleich, G.J. (1981) Purification of Human Eosinophil-Derived Neurotoxin. Proceedings of the National Academy of Sciences of the United States of America, 78, 5165-5169. http://dx.doi.org/10.1073/pnas.78.8.5165

[35] Slifman, N.R., Loegering, D.A., McKean, D.J. and Gleich, G.J. (1986) Ribonuclease Activity Associated with Human Eosinophil-Derived Neurotoxin and Eosinophil Cationic Protein. Journal of Immunology, 137, 2913-2917.

[36] Ohnuki, L.E., Wagner, L.A., Georgelas, A., Loegering, D.A., Checkel, J.L., Plager, D.A. and Gleich, G.J. (2005) Differential Extraction of Eosinophil Granule Proteins. Journal of Immunological Methods, 307, 54-61. http://dx.doi.org/10.1016/j.jim.2005.09.006

[37] Gudkov, A.V. and Komarova, E.A. (2007) Dangerous Habits of a Security Guard: The Two Faces of p53 as a Drug Target. Human Molecular Genetics, 16, 67-72. http://dx.doi.org/10.1093/hmg/ddm052

[38] Lebedeva, I., Rando, R., Ojwang, J., Cossum, P. and Stein, C.A. (2000) Bcl-xL in Prostate Cancer Cells: Effects of Overexpression and Down-Regulation on Chemosensitivity. Cancer Research, 60, 6052-6060.

[39] Shabnam, M.S., Srinivasan, R., Wali, A., Majumdar, S., Joshi, K. and Behera, D. (2004) Expression of p53 Protein and the Apoptotic Regulatory Molecules Bcl-2, Bcl- $\mathrm{X}_{\mathrm{L}}$, and Bax in Locally Advanced Squamous Cell Carcinoma of the Lung. Lung Cancer, 45, 181-188. http://dx.doi.org/10.1016/j.lungcan.2004.01.021

[40] Sharma, J., Srinivasan, R., Majumdar, S., Mir, S., Radotra, B.D. and Wig, J.D. (2005) Bcl-XL Protein Levels Determine Apoptotic Index in Pancreatic Carcinoma. Pancreas, 30, 337-342. http://dx.doi.org/10.1097/01.mpa.0000160282.64451.f1

[41] Mijatovic, T., De Neve, N., Gailly, P., Mathieu, V., Haibe-Kains, B., Bontempi, G. and Kiss, R. (2008) Nucleolus and c-Myc: Potential Targets of Cardenolide-Mediated Antitumor Activity. Molecular Cancer Therapeutics, 7, 1285-1296. http://dx.doi.org/10.1158/1535-7163.MCT-07-2241

[42] Prendergast, G.C. (1999) Mechanisms of Apoptosis by c-Myc. Oncogene, 18, 2967-2987. http://dx.doi.org/10.1038/sj.onc.1202727

[43] Thompson, E.B. (1998) The Many Roles of c-Myc in Apoptosis. Annual Review of Physiology, 60, 575-600. http://dx.doi.org/10.1146/annurev.physiol.60.1.575

[44] Mitchell, K.O., Ricci, M.S., Miyashita, T., Dicker, D.T., Jin, Z., Reed, J.C. and El-Deiry, W.S. (2000) Bax Is a Tran- 
scriptional Target and Mediator of c-Myc-Induced Apoptosis. Cancer Research, 60, 6318-6325.

[45] Jinno, H., Ueda, M., Ozawa, S., Ikeda, T., Kitajima, M., Maeda, T. and Seno, M. (2002) The Cytotoxicity of a Conjugate Composed of Human Epidermal Growth Factor and Eosinophil Cationic Protein. Anticancer Research, 22, 41414145.

[46] Rubin, J., Zagai, U., Blom, K., Trulson, A., Engstrom, A. and Venge, P. (2009) The Coding ECP 434(G>C) Gene Polymorphism Determines the Cytotoxicity of ECP but Has Minor Effects on Fibroblast-Mediated Gel Contraction and No Effect on RNase Activity. Journal of Immunology, 183, 445-451. http://dx.doi.org/10.4049/jimmunol.0803912

[47] Furbert-Harris, P.M., Laniyan, I., Harris, D., Dunston, G.M., Vaughn, T., Abdelnaby, A. and Oredipe, O.A. (2003) Activated Eosinophils Infiltrate MCF-7 Breast Multicellular Tumor Spheroids. Anticancer Research, 23, 71-78.

[48] Walsh, G.M. (2001) Eosinophil Granule Proteins and Their Role in Disease. Current Opinion in Hematology, 8, 28-33. http://dx.doi.org/10.1097/00062752-200101000-00006 